\title{
Umbilical warts: a new entity?
}

\author{
Mayura Nathan
}

\begin{abstract}
Two cases of umbilical warts are described. The occurrence of these lesions was not previously known. In both cases there was a history of longstanding genital warts.
\end{abstract}

(Genitourin Med 1994;70:49-50)

\section{Case report}

CASE 1

A 28 year old single, heterosexual man attended in December 1991 for his urethral discharge, and was found to have chlamydial urethritis. Examination of his partner revealed genital warts in addition to chlamydial cervicitis. In March 1992, he developed two typical genital warts at the base of the shaft. Following initially successful treatment they recurred in October 1992. Examination on this occasion including meatoscopy did not identify any other anogenital warts. However, further examination revealed a solitary wart $(4 \mathrm{~mm})$ that was clinically similar to his genital warts, arising from the umbilicus (fig 1). After infiltration of 3\% Citanest at the

Department of Genitourinary Medicine, Doncaster Royal Infirmary, Doncaster, UK M Nathan

Address for correspondence: Dr P M Nathan, Department of GU

Medicine, Doncaster Royal Infirmary, Armthorpe Road Doncaster, DN2 5LT, UK.

Accepted for publication 13 October 1993

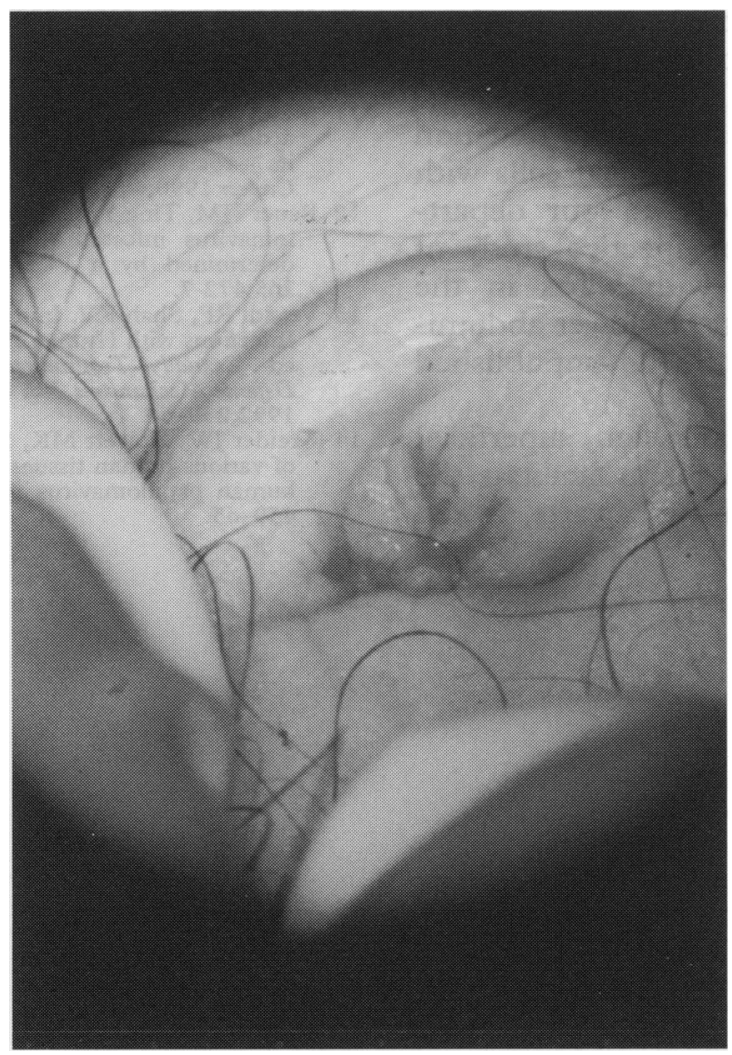

Figure 1 Umbilical wart (magnification $\times 7 \cdot 5$ ).

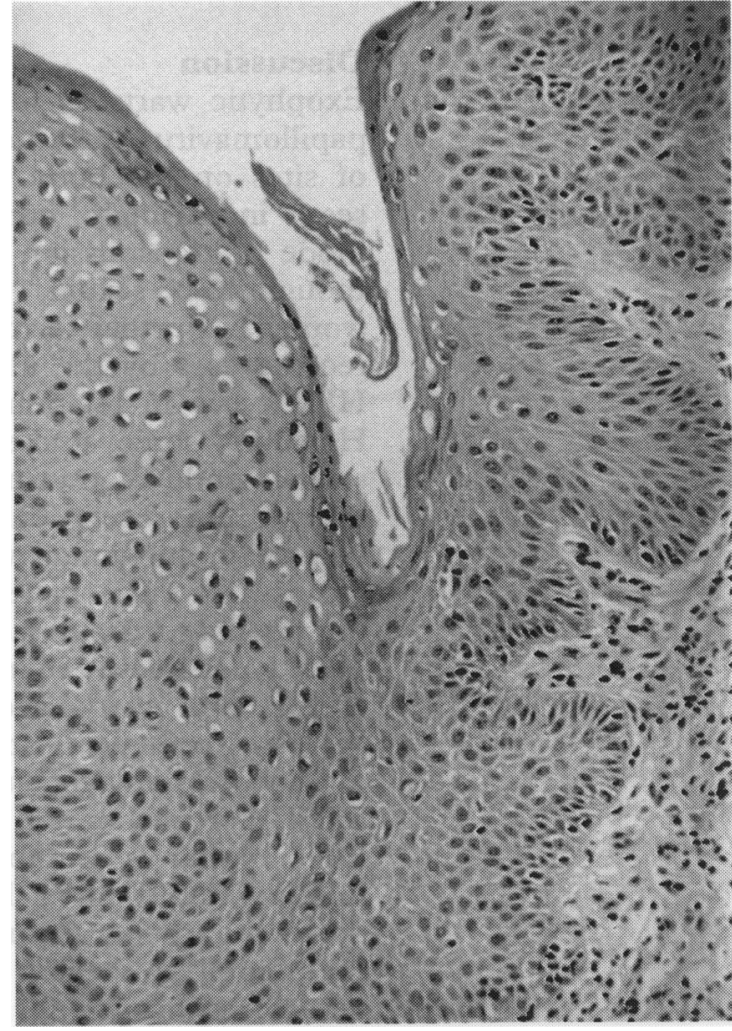

Figure 2 Histology showing koilocytic and dyskeratotic changes of HPV infection $(\times 150)$

base of the wart and completing a punch biopsy for histology, the base of the wart was ablated using $\mathrm{CO}_{2}$ laser. Histology showed evidence of a squamous papilloma with koilocytic and dyskeratotic changes as features of condylomatous wart virus infection (fig 2 ).

\section{CASE 2}

A 30 year old heterosexual man attended in June 1987 with a history of urethral pain and dysuria. He also gave a history of genital warts occurring a year earlier, treated successfully and then recurring six months later. His wife of ten years was examined on a number of occasions and was found free of warts though her smears recorded dyskaryosis with wart virus changes. His examination revealed an external meatal wart and a few warts on the glans. His external warts regressed with treatment but the meatal wart persisted. Urological referral did not succeed in the eradication of his meatal wart. However, with continued treatment, in April 1990 he became free of meatal warts, but meatoscopic examination in June 1990, identified distal urethral warts at a depth of $20 \mathrm{~mm}$. After several unsuccessful treatments he was 
eventually cleared of urethral warts in August 1992, following laser ablation using a Nd-Yag laser. In May 1992, the patient accidentally detected the presence of an umbilical growth and requested advice. On examination with a microscopic aid, a small ( $3 \mathrm{~mm})$ wart was identified. Excision biopsy of the lesion showed histological evidence of wart virus changes similar to case 1 . There were no recurrences noted over a six month period of observation.

\section{Discussion}

Exophytic warts as manifestation of human papillomavirus infection occur on a number of sites on the body. ${ }^{1}$ Anogenital warts are seen increasingly commonly. ${ }^{2}$ The prime mode of transmission of anogenital warts is thought to be sexual, ${ }^{34}$ at least in the younger women. ${ }^{5}$ Further evidence has accrued in recent years by the identification of specific HPV types in relation to anogenital warts. ${ }^{6}$ However, some studies conclude that nonsexual mode of transmission was common, ${ }^{7}$ though the recent data suggest otherwise. ${ }^{8}$ Clinically, anogenital warts spreading to the groins and pubis have been noted. Equally, the possible transmission of common genital HPV types elsewhere in the nose, conjunctiva and the oral cavity have been described..$^{9-11}$ In the cases presented, attempts at HPV typing did not yield any conclusive results. However, this is not uncommon as the success rate of HPV typing is variable irrespective of the method employed. ${ }^{72}$ The relative scarcity of the viral particles in some infected tissues like the genital epithelium may well be another reason responsible for the limited success. ${ }^{13}$ The typical clinical appearance of condyloma acuminatum, the histology and the concomitant presence of anogenital warts in these cases will lend support to the HPV aetiology of the umbilical lesions. However, in experimental models relative resistance to infection of the human abdominal epithelial cells with HPV11 have been noted. ${ }^{14}$ In our department, during a recent prospective study of 182 new male patients with warts in the anogenital region, two cases of lower abdominal wall warts were identified (unpublished data).

Apart from sexual transmission, superficial trauma to the skin is thought to facilitate the transmission of HPV related warts, when exposed. ${ }^{36}$ In the umbilicus, minor trauma during activities like bathing and vigorous exercise or the occurrence of superficial infection is discernible. It is suggested that autoinoculation through bathing or fomites was a likely mode of spread to the umbilicus from the anogenital region in these two cases. An understudied physical aspect of the exophytic warts is their friability and its relation to autoinoculation and transmission. Demonstration of the transmission of genital HPV by routes other than sexual, will be of relevance in cases of alleged sexual abuse. Further detection of similar cases will be necessary for the identification of the HPV types involved.

The author is grateful to Mr Gary Swann and his team from the Media Services Department at the Doncaster Roya Infirmary, for their help with photographic prints.

1 Syrjanen SM. Epidemiology of human papillomavirus (HPV) infections and their associations with genital squamous cell cancer. APMIS 1989;97:957-70.

2 Department of Health and Social Security: Statistical Bulletin on New cases seen at NHS Genito-urinar Medicine Clinics in England, 1976-1986. Statistical Bulletin 2/7/88.

3 Oriel JD. Natural history of genital warts. $\mathrm{Br} \mathcal{F}$ Venereal Dis 1971;47:1-13.

4 Ley C, Bauer HM, Reingold A, et al. Determinants of genital human papillomavirus infection in young genital human papillomavirus infection in young

Koutsky L. Role of epidemiology in defining events that influence transmission and natural history of anogenital influence transmission and natural history of anogenital papillom.

6 Koutsky LA, Galloway DA, Holmes KK. Epidemiology of genital human papillomavirus infection. Epidemiol Rev 1988;10:122-63.

7 Sun-Kuie T, Tew-Hong H, Soo-Kim LT. Is genital human papillomavirus always sexually transmitted? Aust NZ F Obstet Gynaecol 1990;30:240-2.

8 Fairley CK, Chen S, Tabrizi SN, Leeton K, Quinn MA Garland SM. The absence of genital human papillomavirus DNA in virginal women. Int $f$ STD AIDS 1992;3:414-7.

9 Brandsma J, Abramson A, Sciubba J, et al. Papillomavirus infection of the nose. In: Steinberg BM, Brandsma JL infection of the nose. In: Steinberg BM, Brandsma JL, Taichman LB eds. Papillomavirus: Cancer cells.

10 McDonnell PJ, McDonnell JM, Kesis T, et al. Detection of human papillomavirus types 6/11 DNA in conjunctival papillomas by in-situ hybridisation with radioactive probes. Hum Pathol 1987;18:1115-9.

11 Melbye M, Palefsky J, Gonzales J, et al. Immune status as a determinant of human papillomavirus detection and its association with anal epithelial abnormalities. Int Cancer 1990;46:203-6.

12 Bauer HM, Ting Y, Greer CE, et al. Genital human papillomavirus infection in female university students as determined by a PCR-based method. $f A M A$ 1991; 265:472-7.

13 Viscidi RP, Shah KV. Immune Response to Genital Tract Infections with Human Papillomaviruses. In: Quinn CT ed. Sexually Transmitted Diseases: Advances in Hos Defense Mechanisms. vol 8. New York: Raven Press Ltd 1992;239-60.

14 Kreider JW, Howett MK, Stoler MH, et al. Susceptibility of various human tissues to transformation in vivo with human papillomavirus type 11 . Int $\mathcal{f}$ Cancer $1987 ; 39$. 459-65. 